\title{
Sensitivity Injury Tetranychus urticae for Two Types of Sweet Pepper and the Effect of Infection on the Physical and Chemical Characteristics of the Plants. Abd El- Rahman, H. A. and M. S. El-keblawy \\ Plant Protection Research Institute, Agricultural Research Center, Giza, Egypt.
}

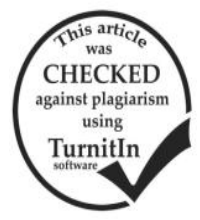

\section{ABSTRACT}

An experiment was conducted during two successive growing seasons of 2015 and 2016 under greenhouse condition ( four screen-houses $9 \mathrm{~m}$ width $\mathrm{x} 40 \mathrm{~m}$ length $\mathrm{x} 2 \mathrm{~m}$ height) were established for investigate the susceptibility of two sweet pepper hybrids to infestation by two spotted spider mite Tetranychus urticae.The sweet pepper hybrids in) Kafr E1-Sheikh-El-HamolEl-Manwfa(showed different susceptibility degree to the aforementioned pest. The data showed that liebergen was the highest density population of T.urticae in seasons of 2015 and 2016 under greenhouse while steric was low density population of T.urticae .Liebergen was the highest sensitivity while steric was the least sensitivity.Out of the two hybrids only one steric rated as low resistant against the two spotted spider mites Tetranychus urticae. The remaining hybrids showed variable degree of resistance to two spotted spider mite Tetranychus urticae. Therefore this hybrids could be recommended for integrated pest management program .

\section{INTRODUCTION}

Tetranychid mites are common pests in agricultural systems causing in many cases, greater economic losses than any other arthropod pests. The twospotted spider mites, Tetranychus urticae is considered as one of the major pests attacking different agricultural crops such as field crops, vegetables, fruits and ornamental plants. The two-spotted spider mites $T$. urticae (Koch) has been extensively studied and the early work was reviewed by Huffaker et al. (1969). T. urticae infests a wide range of economic plants in the field such as cotton (Leigh et al., 1968), strawberry (Sances et al., 1981 and 1982), cucumber (De-ponti, 1980), tomato (Rodriguez et al., 1972), peanuts (Boykin and Campbell, 1982), peppermint (Hollingsworth, 1980).

Sweet pepper is an important agricultural crop. Not only because of its economic importance, but also for the nutritional values of its fruits, mainly due to the fact that they are an excellent source of natural colors and antioxidant compounds (Howard et al., 2000) In this respect, sweet pepper is considered an excellent source of bioactive nutrients, such as carotenoids, vitamin $\mathrm{C}$ and phenolic compounds(Navarro et al, 2006).Hundreds varieties of peppers are now available for the greenhouses. They range widely in size, shape, color, flavor, disease resistance and season of maturity. However, many previous workers indicated that varieties of pepper plants play a great role for improving the growth and productivity (Rembiałkowska et al 2005).

It is generally assumed that environmental factors and agricultural techniques have an effect on the quality of vegetables and fruits (Wang.,2006; Bafeel, and Ibrahim, 2008 and Nunez et al ,2011).In addition pepper is one of the most important exportable crops in Egypt. Pepper crops grown in greenhouses can be seriously damaged by various insects and mites. Salehi et.al.,(2007) Sweet pepper have cytokinins and trace elements ( $\mathrm{Fe}, \mathrm{Cu}, \mathrm{Zn}, \mathrm{Co}, \mathrm{Mo}, \mathrm{Mn}$ and $\mathrm{Ni}$ ) as well as vitamins and amino acids (Zodape et al. 2011).

This study aims to reduce the cost of populations of T. urticae and to allow the start of the sweet pepper growing season earlier under greenhouses with the two hybrids of sweet pepper plants considering growth.

\section{MATERIALS AND METHODS}

Culture techniques:

The two-spotted spider mite, Tetranychaus urticae (Koch) (Acarina: Tetranychidae), was reared according to Dittrich (1962) in colonies obtained from sweet pepper plants from greenhouse plants

Egg deposition and egg- hatching of $T$. urticae:

Five adult females' mites T.urticae of known age were placed on each disc. Numbers of eggs laid were assessed individually on different discs after 24 and 48 hours later Keratum et al. (1994). The number of hatched eggs was also counted 4 days after egg deposition. Assessment was conducted at $25 \pm 2{ }^{\circ} \mathrm{C}$ and $70 \pm 5$ R.H. Each treatment was replicated four times. The same technique was repeated by sweet pepper leaf discs.

Antioxidant enzymes and chlorophyll ( $A$ and $B$ ) concentration

For enzyme assays in plants, $0.5 \mathrm{~g}$ leaf material was homogenized at $0-4^{\circ} \mathrm{C}$ in $3 \mathrm{ml}$ of $50 \mathrm{mM}$ TRIS buffer (pH 7.8), containing $1 \mathrm{mM}$ EDTA-Na2 and 7.5\% polyvinylpyrolidone. The homogenates were centrifuged $\left(12,000 \mathrm{rpm}, 20 \mathrm{~min}, 4^{\circ} \mathrm{C}\right)$, and the total soluble enzyme activities were measured spectrophotometrically in the supernatant (Hafez, 2010). All measurements were carried out at $25^{\circ} \mathrm{C}$, using the model UV-160A spectrophotometer (Shimadzu, Japan). The enzyme assays were tested three times.

Activity of catalase (CAT) was determined spectrophotometrically according to Aebi (1984). Polyphenol oxidase (PPO) activity was determined according to the method described by Malik and Singh (1980). Changes in the absorbance at $495 \mathrm{~nm}$ were recorded every $30 \mathrm{sec}$ intervals for $3 \mathrm{~min}$. Enzyme activity was expressed as the increase in absorbance min-1 g-1 fresh weight. Peroxidase (POX) activity was directly determined of the crude enzyme extract according to a typical procedure proposed by Hammerschmidt et al, (1982). Changes in absorbance at $470 \mathrm{~nm}$ were recorded every $30 \mathrm{sec}$ intervals for $3 \mathrm{~min}$. Enzyme activity was expressed as the increase in absorbance min-1 g-1 fresh weight.

Chlorophyll (Chl.) concentration as $\mathrm{mg} / \mathrm{g}$ fresh weight of one gram fresh leaves was extracted with $5 \mathrm{ml}$ $\mathrm{N}, \mathrm{N}$-dimethyl-formamid for overnight at $5^{\circ} \mathrm{c}$ then estimated Chl. a and b spectrophotometerically at 663 and $647 \mathrm{~nm}$ as described by Moran and Porath (1982). 


\section{Methods of determination NPK:}

Samples of leaves of (steric and liebergen) tissues were dried till constant weight. The dried leaves were grounded to fine powder.0.2gm of the fine was digested using sulphuric acid and perchloric acid (5:1) then the solution was completed to $50 \mathrm{ml}$ using distilled water. The final solution was used to determine nitrogen, phosphorus and potassium as follows:

The nitrogen content in steric and liebergen leaves was determined in all of the before mentioned treatment by kjeldahl method according to Chalmers (1984).Phosphorus was determined according to Chapman and Pratt (1961).Potassium was determined using a flame photometer according to Chapman and Pratt (1961) Potassium percentage was determined by a flame photometer with aid of standard curve of known concentrations of potassium.

\section{Field experiment}

An experiment was conducted in a greenhouse at El-Manwfa village, El- Hamol district,Kafr E1-Sheikhgovernorate; during two successive growing seasons of 2015 and 2016 using new two hybrids sweet pepper for studying the population dynamics in hybrid, sweet pepper. The greenhouse was $510 \mathrm{~m} 2$ with $60 \mathrm{~m}$ long and $8.5 \mathrm{~m}$ wide, divied into 5 rides. Each ridge $90 \mathrm{~cm}$.wide and $60 \mathrm{~m}$ long. Seedling were transplanted on both sides of the ridges at $60 \mathrm{~cm}$. apart nearly. A complete randomized block sides with three replicated for each hybrids were adopted, the tested hybrids which were distributed at random within the replicate. Each plot contained 10 plants thus the area of each ridge was $16.2 \mathrm{~m} 2$.All received the stander cultivation practices that area including organic and mineral fertilization drip irrigation.

Data were statistically analyzed by using $\mathrm{F}$ test, means were compared according Duncan's multiple range test as described by Steel and Torrie (1982)and (Duncan,1955)

Two spotted spider mite T.urticae populations was estimated on sweet pepper leaves of two hybrids. The numbers of Tetranychus urticae was weekly counted on the terminal leaf one each plant. Ten leaves were randomly selected from each plot and examinal using a hand lens.

\section{RESULTS AND DISCUSSION}

1. Biology of the two-spotted spider mites T.urticae:-

One of the important bases of the integrated pest management is the studying of the different effects of biological agents on mite egg deposition and the different responses of the eggs to these agents. These informations are of great importance for the entomologist to reach the different relations of certain importance to the phytophagous mites.

\section{Egg deposition of adult females of T. urticae on} hybrids of sweet pepper:

The data shown in Tables ( 1 and 2$)$ indicated that the mean number of eggs deposited by adult female mites T.urticae on hybrids sweet pepper. The result in suggested that liebergen caused the highest reduction in egg deposition through the first day to five day (30.25: 95.50) followed by steric (20.75: 86.50$)$. In general the effect of T.urticae can be arranged as steric $>$ liebergen to egg deposition of adult females of $T$. urticae on hybrids of sweet pepper.

Table 1. Egg deposition of adult females of $T$. urticae on hybrids of sweet pepper:

\begin{tabular}{lcccccc}
\hline \multirow{2}{*}{ Compounds } & \multicolumn{4}{c}{ No. of egg deposited/5 adults } & \multicolumn{2}{c}{ Mean \pm SD } \\
\hline steric & $\mathbf{1}^{\text {st }}$ day & $\mathbf{2}^{\text {nd }}$ day & $\mathbf{3}^{\text {rd }}$ day & $\mathbf{4}^{\text {th }}$ day & $\mathbf{5}^{\text {tay }}$ day & \\
Liebergen & $20.75 \pm 0.95 \mathrm{c}$ & $42.50 \pm 0.57 \mathrm{c}$ & $57.00 \pm 81 \mathrm{c}$ & $59.25 \pm 0.95 \mathrm{c}$ & $86.50 \pm 1.29 \mathrm{c}$ & $89.60 \pm 0.91 \mathrm{c}$ \\
\hline
\end{tabular}

Table 2. Reduction of adult females of $T$. urticae on hybrids of sweet pepper:

\begin{tabular}{|c|c|c|c|c|c|c|}
\hline \multirow[b]{2}{*}{ Compounds } & \multicolumn{5}{|c|}{ Reduction\% } & \multirow[b]{2}{*}{ Mean } \\
\hline & $\begin{array}{l}1^{\text {st }} \\
\text { day }\end{array}$ & $\begin{array}{l}2^{\text {nd }} \\
\text { day }\end{array}$ & $\begin{array}{l}3^{\text {rd }} \\
\text { day }\end{array}$ & $\begin{array}{l}4^{\text {th }} \\
\text { day }\end{array}$ & $\begin{array}{l}5^{\text {th }} \\
\text { day }\end{array}$ & \\
\hline steric & 71 & 62 & 48 & 21 & 19 & 44.2 \\
\hline Liebergen & 88 & 72 & 60 & 38 & 31 & 57.8 \\
\hline
\end{tabular}

\section{Population of adult mites T.urticae on sweet} pepper during 2015 and 2016 seasons.

The data were shown in Table (3) that liebergen was the highest density population of T.urticae in seasons of 2015 and 2016 under greenhouse while steric was low density population of T.urticae in seasons of 2015 and 2016.This experiment was carried out to sensitivity injury on mite populations of T.urticae so was the highest sensitivity while steric was the least sensitivity to the two hybrids of pepper.

On the other hand steric hybrid showed low liebergen number of T.urticae from month (march to October), the highest density population of T.urticae for hybrid steric(258) was observed in dune .While liebergen was the highest number of T.urticae from month (march to October) while month June was the highest density population of T.urticae for hybrid liebergen (332) . Steric appeared high resistance but liebergen was the lowest resistance to T.urticae on hybrids sweet pepper Thus the author suggest the inclusion of this resistant sweet pepper hybrid in the integrated pest management program.

Table 3. Population of adult mites T.urticae on sweet pepper during 2015 and 2016 seasons.

\begin{tabular}{lcccc}
\hline \multirow{2}{*}{ Months } & \multicolumn{2}{c}{$\begin{array}{c}\text { Mean No.T.urticae } \\
\text { Season 2015 }\end{array}$} & \multicolumn{2}{c}{$\begin{array}{c}\text { Mean No.T.urticae } \\
\text { Season 2016 }\end{array}$} \\
\cline { 2 - 5 } & $\begin{array}{c}\text { Mean } \\
\text { No.T.urticae } \\
\text { to steric }\end{array}$ & $\begin{array}{c}\text { Mean } \\
\text { To.urticae }\end{array}$ & $\begin{array}{c}\text { Mean } \\
\text { No.T.urticae }\end{array}$ & $\begin{array}{c}\text { Mean } \\
\text { No.T.urticae } \\
\text { To Liebergen }\end{array}$ \\
\hline March & 6.0 & 8.0 & 4.0 & 7.0 \\
April & 8.0 & 17.0 & 11.0 & 18.0 \\
May & 156.0 & 233.0 & 188.0 & 212.0 \\
June & 258.0 & 332.0 & 276.0 & 307.0 \\
July & 194.0 & 212.0 & 183.0 & 203.0 \\
August & 125.0 & 163.0 & 107.0 & 112.0 \\
September & 36.0 & 54.0 & 33.0 & 46.0 \\
October & 32.0 & 44.0 & 15.0 & 33.0 \\
\hline
\end{tabular}




\section{Determination of NPK in sweet pepper:}

Some investigaors found that the supply and absorption of minerals were always postively correlated with pest infestation and that analysis of the host leaves may be valuable in nutrition studies of phytophagous pests (Highland and Robrts 1984 and Roinien and Tahvanaien 1989).

Thus the determination of such minerals as nitrogen, potassium and phosphours in different host plant leaves used to rear. The data in Table (4) illustrate the rate of NPK for tow host plants steric and liebergen. It is clear that steric has the highest rates of the three elements under study(6.888, 0.675 and 2.464) nitrogen, potassium and phosphours. While liebergen plants have the lowest rates in the three elements(5.938, 0.464and $1.833)$. The rate of potassium meq/ $100 \mathrm{gm}$ dry weight in the two host plants was steric and liebergen. The rate of nitrogen as NO3 meq/ 100 gm.d.w. in the two hybrids sweet pepper. The rate of phosphours as meq/ 100 gm.d.w. in the two hybrids sweet pepper was steric and liebergen.

Table 4. Determination of NPK for steric and liebergen leaves.

\begin{tabular}{lccc}
\hline NO & N Mg/L & P Mg/L & K Mg/L \\
\hline steric & 6.888 & 0.675 & 2.464 \\
Liebergen & 5.938 & 0.464 & 1.833 \\
\hline
\end{tabular}

The following points can be concluded from the results on the effect of different rates of the three elements in the two hybrids sweet pepper was steric and liebergen to spider mites T.urticae .

5. Determination of antioxidant enzymes and chlorophyll (A and B) to sweet pepper hybrids.

The data in figure (1 and 2) showed that estimation of enzymes in plants illustrated the extent of the difference between the different types and the extent of its relationship with the numbers of the population of the spider mite, steric higher than the kind of liebergen in the concentrations of enzyme and that meaning that the concentrations of enzyme is the reasons for the low number of population on the plants sweet pepper as Liebergen (yellow) the largest population and the ratio of the concentrations of enzymes and at least this shows that these concentrations have an inverse relationship existing population numbers. The results in figure (3)showed that steric was much higher degree contains phenols.

The data in figure (4) showed that the chlorophyll outside the scope of the competition between the two species in the presence of the population on sweet pepper. Park,(2002)chlorophyll content was reduced by approximately 55 and $80 \%$, and greenness was reduced by approximately 50 and $80 \%$ by feeding by immature and adult $\mathrm{T}$. urticae, respectively. Jack,(1983)chlorophyll was reduced in proportion to the degree of injury sustained.
Fig. 1. Determination of antioxidant enzymes to sweet pepper hybrids.

Fig. 2. Determination of peroxidase activity to sweet pepper hybrids.

Fig. 3. Determination of polyphenol oxidase to sweet pepper hybrids. 
Fig. 4. Determination of chlorophyll (A) to sweet pepper hybrids.

The data in figure $\left({ }^{\circ}\right)$ showed that steric of sweet pepper was higher than Liebergen and this shows that the chlorophyll (b) has to do with the number of inhabitants of the spider mite. $\left.\operatorname{Landeros}\left(r_{+}\right)^{0}\right)$ The data indicate that increased mite density coincides with a decrease in the net photosynthetic rate, transpiration and chlorophyll content. Higher mite densities on leaves cause stomata to remain open for longer periods, which allows a greater loss of water. Spider mite densities of 10 and 50 mites per leaf cause a reduction in flower stem length of 17 and $26 \%$, respectively, as compared to plants with no mites present.

Fig. 5. Determination of chlorophyll (B)to sweet pepper hybrids.

6. Population trend and susceptibility degrees of T.urticae to the tested pepper hybrids during 2015 and 2016 seasons.

Out of the two sweet pepper hybrids liebergen hybrid had significantly high mean number (4.28)of spider mite per leaf as compared to the other tested hybrids steric with 2.54 spider mite per leaf ranked second in its susceptibility. Steric low numbers the pest (2.14 and 2.27 ) spider mite per leaf, respectively and appeared low resistance (S) hybrids on basis of results while liebergen was high resistance (HS) hybrids on basis of results.

Table 5. Susceptibility degrees of T.urticae to the tested pepper hybrids during 2015 and 2016 seasons.

\begin{tabular}{lccccc}
\hline NO & Hybrids & \multicolumn{2}{c}{ Tetranychus.urticae } & Susceptibility \\
& $\mathbf{2 0 1 5}$ & $\mathbf{2 0 1 6}$ & Mean \pm SD & degree \\
\hline 1 & Liebergen & 4.24 & 4.48 & $4.28 \pm 0.04$ & HS \\
2 & steric & 2.14 & 2.27 & $2.54 \pm 0.42$ & S \\
----- & Mean & 3.19 & 3.37 & 1.88 & --------------- \\
\hline \multicolumn{7}{l}{ HS - Highly susceptibile } & \multicolumn{5}{l}{ S- Susceptibile }
\end{tabular}

It could be concluded that out of the two sweet pepper hybrids evaluated for their resistance.hybrid was rated as resistant to Tetranychus.urticae. Thus the author suggest the inclusion of this resistant sweet pepper hybrid in the integrated pest management program.

\section{REFERENCES}

Aebi ,H.( 1984 .(Catalase in vitro. Methods Enzymol . $.1 Y T_{-1} \mid 1: 1.0$

Bafeel, S.O. and M.M. Ibrahim, (2008). Antioxidants and accumulation of $\alpha$-tocopherol induce chilling tolerance in Medicago sativa. Int. J. Agric. Biol., 10: 593-598.

Boykin, L. S. and W. V. Campbell (1982). Rate of population increase of the two- spotted spider mite (Acari: Tetranychidae) on peanut leaves treated with pesticides. J. Econ. Entomol, (75): 966-971.

Chalmers, R.A. (1984). Methods of proline analysis Publ.Chichester,Halsted press.Addivision of john Wiley Sons. New York, 371p.

Chapman, H.D.and P.F.Pratt (1961). Methods of analysis for soils, plants and waters.California. Univ.Devision of Agric.Sciences.

De-Ponti, O.M.B (1980). Resistance in Cucmis sativus L. to Tetranychus urticae Koch 6. Comparison of near isogenic bitter and non- bitter varieties for resistance. Euphytica, (29): 261-265.

Dittrich, V. (1962). A comparative study of toxicological test methods on a population of the two-spotted spider mite (T.urticae). J. Econ. Entomol. 55 (5) 644- 648.

Duncan,D.B(1955).;Multiple range and Multiple F tests.Biometrics 11:1-42.

Hafez, Y. M. (2010). Control of Botrytis cinerea by the resistance inducers benzothiadiazole $(\mathrm{BTH})$ and hydrogen peroxide on white pepper fruits under postharvest storage. Acta. Phytopathol. Entomol. Hung., 45 (1): 13-29.

Hammerschmidt, R., E.M. Nuckles and J. Kuć,( 1982). Association of enhanced peroxidase activity with induced systemic resistance of cucumber to Colletotrichum lagenarium. Physiol. Plant Pathol., 20(1):73-82.

Highland, A. and Robrts, U. (1984). Spider mite webbing II. The effect of webbing removal on egg hatchability. Comparative Biochem Physiol 51: 457- 462 . 
HoIlingsworth, C.S. (1980). Two- spotted spider mite, Tetranychus urticae in Oregon pepper mint, Mentha piperita: Sampling population dynamic and economic injury. Ph.D. Thesis, Oregon State University. Corvallis, pp. 159.

Howard, L.R., S.T. Talcott, C.H. Brenes and B. Villalon. (2000). Changes in phytochemical and antioxidant activity of selected pepper cultivars (Capsicum species) as influenced by maturity. $J$. Agric. Food Chem 48:1713-1720.

Huffaker, C. B.; M. Van De Vrie and J.A. Me Murtry (1969). The ecology of tetrancychid mites and their natural control. A Rev .Entomol,(14): 125 174.

Jack,A,F.( 1983). Comparison of two Phytoseiulus species as predators of twospotted spider mites on greenhouse ornamentals. Environmental Entomology 10: 524-527.

Keratum, A. , Y.; H. Anber; M.M. Essawy and F.L ElShahawi (1994). The effect of permethrin residues on the activity of the predators Phytoseiulus persimilis and Amblyseius fallacis. Alex. Sci. Exch, 15(1): 67-82.

Landeros, A, C( 2015). Biology and natural enemies of Tetranychus urticae in sweet pepper. Manejo Integrado de Plagas y Agroecologia. Centro Agronomico Tropical de Investigacion y Ensenanza, Turrialba, Costa Rica, 74: 34- 40.

Leigh, T.F.; R.E. Hunter and A.H. Hyer (1968). Spider mite effects on yield and quality of four cotton varirties. Calif. Agric. (22): 4-5.

Malik, C. P. and M. B. Singh. (1980). In: Plant Emynology and Histoenzymology. Kalyani Publishers. Indian and printed in Navin. Shanndara. Delhi PP. 54-56.

Moran, R. and D. Porath, (1982). Chlorophyll determination in intact tissues using N,NDimethyl formamide. Plant Physiol., 69: 13701381.

Navarro, H.;J. Demi, S. Uzun and V. Ceyhan, (2006)The effects of different greenhouse covering materials on energy requiement, growth and yield of aubergine. Energy, Vo. 31 (12): 1781788 .
Nunez,D; Daniel; J.Grimaldo and C.D.Lourdes (2011). Nitrogen fertilization effect on Antioxidants Compounds in Fruits of Chili Pepper Capsicum chinense/ Int. J. Agric. Biol., Vol. 13.

Park,J,G( 2002). Large scale production and release of the predatory mites Pytoseiulus macropilis (Banks) to control Tetranychus urticae Koch on commercial strawberry plantations. Bull. Ent. Soc. Egypt, Econ. Ser. Num. 33.153-163.

Rembiałkowska E., Hallmann E., Szafirowska A. (2005). Nutritive quality of tomato fruits from organic and conventional cultivation. Culinary Arts \& Sciences V. Warsaw Agric. Univ. Poland: 193-202.7.

Rodriguez, J.C.; D. E. Knavel and O. J. Aina (1972). Studies in the resistance of tomato to mites. J. Econ. Entomol, (65): 50-53.

Roinien,V,J and Tahvanaien,J,Y( 1989). Protected cultivation of sweet pepper hybrids under nethouse in Indian conditions. Acta Horticulturae, 659: 515- 521 .

Salehi,M.,K.Izadpanah and M.siampour,(2007). Characterization of a phytoplasma associated with cabbage yellows in Iran.Plant Dis.,91:625630.

Sances, F.V.; J.A. Wyman; LP. Ting; R. Van Steenwyk and E.R. Oatman (1981). Spider mite interactions with photosynthesis, transpiration and productvity of strawberry. Environ. Entomol, (10): 442-448.

Sances, F.V.; N.C. Toscano; E.R. Oatman; L.F. Lapre; M.V. Johnson and V. Voth (1982). Reduction in plants processes by Tetranychus urticae feeding on strawberry. Environ. Entomol.(11):733-737.

Steel ,Y.F.and Torrie, H. N.( 1982). Protected cultivation of sweet pepper hybrids under nethouse in Indian conditions. Acta Horticul. 659: $515-521$

Wang, S.Y., (2006). Effect of pre-harvest conditions on antioxidant capacity in fruits. Acta Hort., 712: 299-305.

Zodape, D.; Y. Sandeep K., Dhillon,T. S and Parminder, S( 2011) Protected cultivation of sweet pepper hybrids under net-house in Indian conditions. Acta Horticul. 659: 515-521.

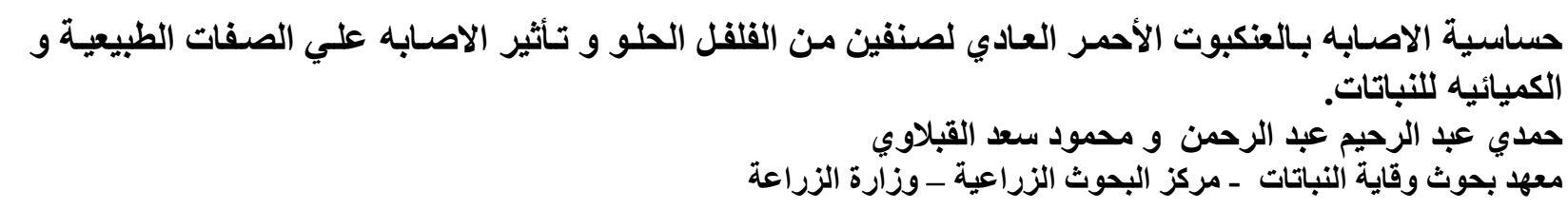

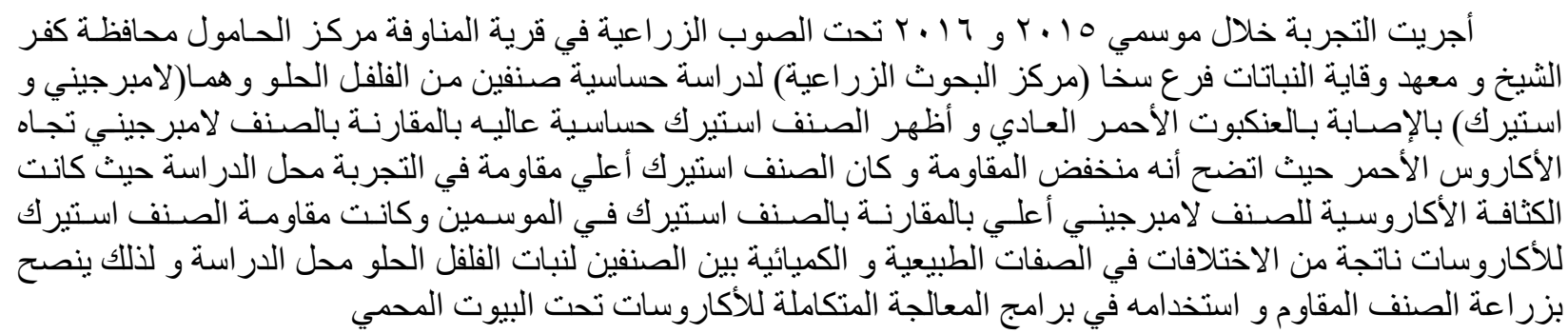

